\title{
EVOLUTION OF CONSUMER PROTECTION LAW IN THE LIGHT OF THE PROPOSAL FOR A HORIZONTAL DIRECTIVE ON CONSUMER RIGHTS AND ROME I REGULATION
}

\author{
ANNA LUCZAK
}

\section{INTRODUCTION}

It can be observed that a new consumer protection policy was launched with the EEC's Preliminary Programme for a consumer protection and information policy in April 1975. This changed the way a consumer was defined, stating that "The consumer is now seen not only as a buyer and user of goods and services for personal, family or group, but also as a person interested in various aspects of social life, that may directly or indirectly affect him as a consumer."

The Programme also contained five fundamental rights, which can be called the Consumer Code:

- the right to health and safety,

- the right to the protection of economic interests,

- the right to compensation,

- the right to information and education

- the right to representation.

The following decades brought subsequent, non-binding initiatives and actions undertaken mainly by the European Commission. The consumer protection policy became an official policy of the EU by the Treaty on European Union, which amended the Treaty on Establishing the European Community; however, it still was not a sufficient legal basis to enact consumer protection acts. The present minimum level of consumer protection was defined in Article 153 of the Amsterdam Treaty.

According to the new EU Consumer Policy Strategy for 2007-2013, there are two general objectives set by the European Commission: to ensure a high level of consumer protection and to ensure the efficient application of consumer protection legislation, especially by means of cooperating in the enforcement thereof, disclosing information and providing education and legal means of recourse. A recent review of existing EU consumer law has led to a Proposal for a Horizontal Directive on Consumer Rights, which 
changes harmonization policy and is generating intense discussion on the future of European consumer law and its impact on domestic law regimes in Member States, especially in the field of private law. The rapid growth of cross-border transactions concluded by individuals and professionals influenced the decision to convert the Rome Convention into the Rome I Regulation, and it seems necessary to discuss how the rules of protection of consumers by institutions of private international law have evolved. In order to give a brief but thorough analysis of consumer protection law it is vital to describe the concept of the consumer in the European Union and review the Consumer Acquis.

\section{THE CONCEPT AND NOTION OF A CONSUMER IN EUROPEAN LAW}

The scope of consumer protection depends on the way the notion of a consumer is defined in European law. Definitions can also be found in sources of European procedural law, e.g. Brussels I Regulation 44/2001, but mainly this is the subject of directives. The question arises of whether the definition should be narrowed or extended to legal persons, i.e. businesspersons concluding atypical contracts and the problem of "mixed" purpose transactions. Positive law by EU institutions, in particular TEU, TEC, the Treaty establishing EURATOM, accession treaties, and general principles of law constitute the system of primary EU law. The Treaty of Rome was established on $25^{\text {th }}$ March 1957 as the legal basis of the European Economic Community (EEC), in addition to the Treaty establishing the existence of the European Coal and Steal Community (ECSC). The objectives which the Treaty was to serve were outlined in Article 2 as follows:

1. establishing a common market,

2. progressively approximating the economic policies of the Member States,

3. promoting the harmonious development of economic activities,

4. promoting sustainable and balanced economic growth and increased stability,

5. accelerate the raising of living standards by strengthening links between Member States.

The Treaty operates on the assumption that by providing a high level of competitiveness in the emerging internal markets, further interference by the legislature directly introducing legislation to protect consumer interests is unnecessary. The signing of the Treaty of Maastricht in 1992 was preceded by the holding of two conferences in Rome. The Treaty created the European Union and institutional framework for its operation as well as confirmed the desire to build an internal market and promote particular economic policies. In addition, among the purposes for which the TUE was established are raising standards of living and quality of life and achieving economic and social cohesion. Instruments serving the intentions of European Union legislation are:

1. common commercial policy, 
2. adopting a system allowing for undistorted competition within an emerging internal market,

3. supporting research and technological development,

4. contribute to the strengthening of consumer protection.

According to further provisions of the TEU, the demand for the strengthening of consumer protection shall be achieved through:

1) taking measures aimed at approximation of laws and regulations of the Member States

2) supporting and complementing the policies pursued by Member States to protect health, safety and economic interests and to provide adequate information to consumers. The Treaty of Amsterdam introduced in Title XIV the measures covered in Art. 153. According to its stipulations, a high level of health, safety and economic interests are protected by the European Community by promoting the right to information and education and the creation of organizations defending consumer interests and consumer rights.

A very important role of the Amsterdam Treaty was to determine the legal basis for regulatory acts designating a minimum standard of protection (minimum harmonization) in order to develop pro-consumer policy under article 95 TEC.

With regard to a number of EC consumer directives, the consumer is defined in the following ways ${ }^{1}$ :

1. under art. 2 of Directive $85 / 577^{2}$, 'consumer' means a natural person who in transactions covered by this Directive is acting for purposes which can be regarded as outside his trade or profession,

2. under art. 2(4) of Directive 90/3143, 'consumer' means a person which receives or agrees to receive a package ('the principal contractor') or any person on whose behalf the principal contractor agrees to purchase the package ('the other beneficiaries') or any person to whom the principal contractor or any of the other beneficiaries transfer the package,

3. by virtue of art. 2 of Directive $94 / 47^{4}$ a consumer is called a 'purchaser' and shall mean any natural person who, acting in transactions covered by this Directive for purposes which may be me regarded as outside his professional activity, has the right which is the subject of the contract transferred to him or for whom the right which is the subject of the contract is established.

4. Directives relating to consumer protection include various and incoherent definitions of 'consumer' and may cause problems when it comes to the legislative process of application of consumer law acquis. The reason for these inconsistencies is the minimum

\footnotetext{
${ }^{1}$ Alexander J Belohlavek, Rome I Regulation, Rome convention: Commentary, vol. 1 (C.H. Beck 2010); see also EU Consumer Law Compendium available at: $<$ www.eu-consumerlaw.org > accessed September 2011.

${ }^{2}$ Council Directive 85/577 EEC of 20 December 1985 to protect the consumer in respect of contracts negotiated away from business premises [1985] OJ L372/31

${ }^{3}$ Council Directive 90/314/EEC of 13 June 1990 on package travel, package holidays and package tour [1990]

OJ L158/59.

${ }^{4}$ European Parliament and the Council Directive 94/47/EC of 26 October 1994 on the protection of purchaser in respect of certain aspects of contracts relating to the purchase of the right to use immovable properties on a timeshare basis OJ L 280/83.
} 
harmonization clause, which permits Member States to introduce or maintain in force provisions offering consumers a higher level of protection than that provided by the directive.

In some European countries, such as Austria, Spain and Greece, legal persons can also be consumers, and additionally in France political parties may be consumers. Each EU country is responsible for proper application of EU law in that country.

In the case of different national interpretations, each Member State court can ask the European Court of Justice for advice using a procedure called the preliminary ruling procedure. Art. 19 of the Treaty on European Union stipulates that the preceding can be done ' $(. .$.$) to ensure that in the$ interpretation and application of the Treaties the law is observed.' It ensures that EU legislation is interpreted and applied in the same way in all EU countries.

The Court of Justice has dealt with many interesting cases concerning the interpretation and application of European consumer protection law.

In the Judgment of the Court in the Di Pinto case ${ }^{5}$ the Court held that the protection in Directive 85/577 may not benefit professionals carrying out activities regulated under the Directive, which itself limits the scope of its protection to individuals, and at the same time admitted that the directive does not limit the powers of the national legislature to define a broader class of persons entitled to protection. In this case, Mr. Di Pinto was the manager of a French private limited liability company that published a periodical in which businesses were advertised for sale. For the purpose of collecting such advertisements, Mr. Di Pinto employed representatives to canvass, either at their homes or at their places of business, those traders who expressed an intention to sell their business following initial contact by phone. On 28 March 1989 the Regional Court in Paris imposed on Mr. Di Pinto a one-year suspended prison sentence and a fine, as the contracts concluded by representatives of Mr. Di Pinto in the course of their canvassing were accompanied by immediate payment of the price of the service (depending on the format of the advertisement), and those contracts did not make reference to the consumer's right of cancellation. In view of the above facts, the ECJ did not share the European Commission's view favouring the application of the directive in such a case, and held that a trader, when canvassed in connection with the sale of his business, finds himself in an unprepared state similar to that of an ordinary consumer.

When considering questions concerning the interpretation of the provisions of that directive, in the Bayerische Hypotheken-und Wechselbank $A G$ v. Edgard Dietzinger case ${ }^{6}$ the ECJ followed the line of thought established in previous case law according to which an individual who enters into a contract for a bank guarantee on behalf of a professional actor, although the same acts in commercial, does not deserve the protection guaranteed by Directive 85/577/EEC.

\footnotetext{
${ }^{5}$ Case C-361/89, Criminal proceedings against Patrice Di Pinto, [1991] ECR I-01189.

${ }^{6}$ Case C-45/96, Bayerische Hypotheken- und Wechselbank AG v Edgard Dietzinger [1998] ECR I-01199
} 


\section{REVIEW OF CONSUMER PROTECTION ACQUIS}

In recent decades we can observe the process of 'Europeanization' of law, including private law. Europeanization is a feature of European legal culture based on inter alia Greek philosophy, Judeo-Christian ethics and ius commune. It is a complex phenomenon involving coverage not only of rights but also such disciplines as economics, political science, sociology and international relations.

After joining the European Union, the internal law of a Member State is subjected to the process of harmonization. This is based on 'the introduction of compliance, ordering, for a set of individual elements'. This process makes it easier to facilitate economic integration through the systematization and arrangement of internal legal orders, and thus the introduction of uniform rules not only brings an even level of consumer protection but also increases the chances of entities acting professionally in the internal market.

The activities undertaken within the framework of legal systems are characterized by complexity, both when it comes to regulation and the application of law.

Harmonization may be based on one of the following methods:

1. uniformity, which means replacing internal law with that of a unified legal system; an example of legislation aimed at harmonizing national laws is the Rome Convention of 1980 on the law applicable to contractual relations,

2. approximation, which is a method of implementation by means of directives

3. complement-appropriate in the case of norms and technical standards - coordination which is not intended to change the internal law of a Member State, but through joint provisions added to existing national laws, coordination of the effects of these rights,

4. persuasion as a way of harmonization achieved through non-binding soft law instruments such as recommendations and opinions

It is clear that the main motivation of the so-called protection of the weaker contracting party is the consideration of ensuring the free movement of goods and services in the internal market. The objectives of consumer protection in EU law are rooted in the Treaty on European Union; the Treaty of Amsterdam has helped to strengthen this protection in its horizontal aspect.

The problem of implementing directives related to consumer law was influenced by the harmonization of European contract law. Debate over the shape of harmonization processes was initiated by resolutions of the European Parliament from 1989 and 1994 on efforts to initiate a European Code of Private Law project. The European Commission issued the following documents significant for the unification of private law:

1. Communication from the Commission to the Council and the European Parliament on European Contract $\mathrm{Law}^{7}$,

\footnotetext{
${ }^{7}$ COM (2001) 398 final, 11.07.2001 (OJ 2001 C255/01).
} 


\section{Communication from the Commission to the European Parliament and the Council. A more coherent European Contract Law; An Action Plan ${ }^{8}$.}

The first of the aforementioned documents was intended to initiate discussions among the European Parliament, the Council of the European Union, representatives of the science of law, lawyers, businesses and consumer organizations and other stakeholders on key issues concerning European contract law. In particular, the European Commission was seeking solutions to the following issues:

1. the relationship between national rules of the conclusion, interpretation and performance of cross-border contracts and proper functioning of the Internal Market,

2. the consequences of actions taken so far conducted in the framework of sectoral harmonization and related inconsistencies in the framework of EU law,

3. the sectoral approach, which may cause problems of non-uniform implementation of European law and its application in Member States' national law systems,

4. additional costs of cross-border contracts that may deter professionals from entering into a contract with consumers from other EU countries This document was a call to hold public consultations on the problems resulting from differences in the law of contracts and the related possibility of harmonization of private law.

In addition to a presentation of the legal situation in the field of contract law and an analysis of the existing acquis communautaire, the EC proposed variants of possible actions to solve the aforementioned problems, expressed in the following options:

1. finding solutions to problems through market mechanisms instead of enacting a regulatory framework by the European Parliament,

2. promotion and advancement of non-binding common contract law principles,

3. clarifying and improving existing European contract law in order to make it more transparent and easier in application,

4. enacting a new optional instrument at the European-wide level

The Action Plan suggests proposals to explore options II, III and IV. Option II was defined as the Common Frame of Reference. The idea underlying this research project was to prevent further fragmentation and to promote consolidation of European contract law by setting common rules on the definition of legal concepts contained in the instruments of EU law. A Draft of the Common Frame of Reference would also facilitate the process of interpretation of directives by the ECJ.

The Draft of the Common Frame of Reference was developed in 2005 by an international group of lawyers and published in 2008 under the name 'The principles, definitions and models of European private law. Draft Common Frame of Reference. Temporary draft.' The project is based on the provisions of the Principles of European Contract Law, the principles derived from the acquis communautaire and legal traditions of individual European

${ }^{8}$ COM (2003) 68 final, 12.02.2003 (OJ 2003 C63/01) 
states $^{9}$. The scope of application covers transactions which are made in the course of professional and semi-professional activity.

Under the Proposal for a Horizontal Directive on Consumer Rights, four fundamental directives of EU consumer law were reviewed:

1. Directive $85 / 577 / \mathrm{EEC}$,

2. Directive $93 / 13 / \mathrm{EEC}^{10}$

3. Directive $97 / 7 / \mathrm{EC},{ }^{11}$

4. Directive $99 / 44 /$ EC $^{12}$

These directives are being merged into one act based on the full

\section{harmonization clause.}

For entrepreneurs, the proposed solutions would bring lower costs for transactions including a cross-border element. The project is based on art. 95 of the EC Treaty, while respecting the principles of subsidiarity and proportionality. In accordance with the requirement of subsidiarity set out in Article 5 of the Treaty, the Community shall take action in areas not within its exclusive competence only if Member States cannot achieve the objectives of the proposed action in sufficient detail. However, the principle of proportionality means that only the most important provisions of consumer contract law can be changed. By virtue of art. 5 of the Proposal, the consumer shall be protected by a broadly-defined information duty concerning:

1. the identity of the trader and the arrangements for delivery, whether he is contracting with the trader or with an intermediary acting on behalf of another consumer,

2. the information on arrangements for payment, delivery, performance and the complaint handling policy when distance and off-premises contracts are concluded,

3. any arrangement resulting in the consumer paying a deposit to the trader, including an arrangement whereby an amount is blocked on the consumer's credit or debit card,

4. in case of distance contracts, information shall be given in an appropriate form meeting the technical constrains of certain means of electronic communication,

5. the existence of a right of withdrawal, where applicable,

6. the existence and the conditions of after-sales service and commercial guarantees, where applicable,

7. the duration of the contract where applicable or if the contract is openended,

8. the conditions for terminating the contract,

9. the minimum duration of the consumer's obligations under the contract, where applicable,

\footnotetext{
${ }^{9}$ H Eidenmuller, F Faust, HCh Grigoleit, N Jansen, G Wagner, R Zimmerman, The Common Frame of References for European Private Law: Policy Choices and Codification Problems, $<$ http://www.ssrn.com/SSRN-id-1269270.pdf $>$ accessed August 2011.

${ }^{10}$ Council Directive 93/13/EEC of 5 April 1993 on unfair terms in consumer contracts, [1995] OJ L095/29.

${ }^{11}$ The European Parliament and the Council Directive 97/7/EC of 20 May 1997 on the protection of consumers in respect of distance contracts [1997] OJ L144/19.

12 The European Parliament and the Council Directive 99/44/EC of 25 May 1999 on certain aspects of the sale of consumer goods and associated guarantees[1999] OJ L171/12.
} 
10. the existence and the conditions of deposits or other financial guarantees to be paid or provided by the consumer at the request of the trader.

Another important difference is the provision on the right of

withdrawal. According to art.12 of the Proposal there is one uniform period of fourteen days in all Member States to withdraw from a distance or offpremises contract, without need to provide any reason.

There are some exceptions excluding the right of withdrawal. When the consumer has concluded a distance contract, he cannot exercise his right to withdrawal when: a) the performance of services has begun, with the consumer's prior express consent, before the end of the fourteen day period; b) (the contract concerns) the supply of goods or services for which the price is dependent on fluctuations in the financial market which cannot be controlled by the trader; c) the supply of goods (is) made to the consumer's specifications or clearly personalized or which are liable to deteriorate or expire rapidly; d) (the contract concerns) the supply of wine, the price of which has been agreed upon at the time of the conclusion of the sales contract, the delivery of which can only take place beyond the time-limit; e) (the contract concerns) the supply of sealed audio or video recordings or computer software which were unsealed by the consumer; f) (the contract concerns) the supply of newspapers, periodicals and magazines; g) (the contract concerns) gaming and lottery services; h) (the contract has been) concluded at an auction.

\section{UNIFICATION OF EUROPEAN PROCEDURAL LAW, ROME I REGULATION AND ITS IMPACT ON PROTECTION OF CONSUMERS}

The Rome I Regulation ${ }^{13}$ replaced the Rome convention ${ }^{14}$ in 2009. In the Rome convention protection of consumers was regulated by virtue of art. 5, according to which the consumer was protected by the following provisions:

1. if in that country the conclusion of the contract was preceded by a specific invitation addressed to him or by advertising, and he had taken in that country all the steps necessary on his part for the conclusion of the contract, or

2. if the other party or his agent received the consumer's order in that country, or

3. if the contract is for the sale of goods and the consumer traveled from that country to another country and there gave his order, provided that the consumer's journey was arranged by the seller for the purpose of inducing the consumer to buy

The provisions of the Rome convention became obsolete and did not take into account the rapid growth of contracts concluded by electronic means

\footnotetext{
13 The European Parliament and the Council Regulation 593/2008 of 17 June 2008 on the law applicable to contractual obligations [2008] L177/6.

141980 Rome Convention on the law applicable to contractual obligations (consolidated version) [1998] OJ C027/34.
} 
of communication. That was one of the reasons for converting the international agreement into European regulation. This issue was the subject of a document from the European Commission issued as a Green Paper. ${ }^{15}$ In the preamble to the Rome I Regulation it is stipulated that where a contract is concluded with party who is regarded as a weaker one, its protection should include choice of law rules; this indicates a higher level of protection than that guaranteed by rules of a general nature.

Terms of consumer contracts are set out in article 6 of the Regulation. In contrast to the provisions of the Convention consumer contracts are subject to those provisions relevant to the consumer's habitual residence upon meeting one of the specified conditions, inter alia if the contract is concluded with an entrepreneur in respect of his activities and the entrepreneur:

1. carries out his business or profession in the consumer's habitual residence,

2. in any way directs his activities to that Member State or several of these countries.

\section{COnClusions}

Consumer protection policy in the European Union is undergoing a deep and necessary reform influenced by many factors, including the growth of cross-boarder consumer contracts concluded by electronic means of communication. A review of existing consumer protection acquis shows the weak aspects of the European regulatory framework. There are inconsistencies, gaps and fragmentation in European consumer protection law. The need for simplification by consolidation of acts of secondary law is obvious in the present circumstances, as such may contribute to strengthening consumer confidence in cross-border shopping and provide benefits to traders by reducing transaction costs.

\footnotetext{
${ }^{15}$ Commission, 'Green paper on the conversion of the Rome Convention of 1980 on the law applicable to contractual obligations into a Community instrument and its modernization' COM (2002) 654 final.
} 